\title{
Development of population-based newborn screening for severe combined immunodeficiency
}

\author{
Kee Chan, MS, ${ }^{\text {a,b }}$ and Jennifer M. Puck, MD ${ }^{\mathbf{a}}$ Bethesda, Md, and New Haven, Conn
}

\begin{abstract}
Background: Severe combined immunodeficiency (SCID) is a treatable, inherited lack of cellular and humoral immunity caused by diverse mutations in several different genes and leading to death in infancy unless immune reconstitution is provided. Currently no population screening exists for SCID, but early diagnosis would improve outcome.

Objective: Because all patients with SCID make few or no T cells, we asked whether the absence of T-cell receptor excision circles (TRECs), DNA episomes in newly formed T cells, could identify SCID regardless of genotype.

Methods: DNA isolated from dried blood spots was assayed by real-time PCR to quantitate TRECs. Control PCR was performed on a segment of the $\beta$-actin gene. After pilot studies with adult and cord blood control subjects, blood from SCID patients was spotted onto filters and tested, followed by screening of actual blood spots from the Maryland Newborn Screening Program. Finally, newborn blood spots were recovered and tested from 2 infants after their diagnosis of SCID.

Results: In contrast to filters from the newborn screening program, which had a mean of 1020 TRECs in two 3-mm punches, samples from 23 infants with SCID had $<30$ TRECs. The newborn screening filter was retrieved from a state laboratory for one of these infants plus another infant who had died of SCID previously; although both samples had detectable $\beta$-actin DNA, neither had TRECs.

Conclusion: TRECs are a stable analyte that can identify T-cell lymphopenia in newborn dried blood spots so that infants with SCID can receive early, life-saving treatment. (J Allergy Clin Immunol 2005;115:391-8.)
\end{abstract}

Key words: SCID, newborn screening, TREC, T-cell receptor excision circle, T-cell maturation, early intervention, primary immunodeficiency, cost-effectiveness, bone marrow transplant, dried blood spots

Severe combined immunodeficiency (SCID) represents a spectrum of genetic disorders characterized by profound

From a the National Human Genome Research Institute, National Institutes of Health; and ${ }^{\mathrm{b}}$ Yale University School of Medicine, Epidemiology and Public Health.

Supported by National Human Genome Research Institute Division of Intramural Research, National Institutes of Health.

Received for publication August 30, 2004; revised September 28, 2004; accepted for publication October 4, 2004.

Available online January 4, 2005.

Reprint requests: Jennifer M. Puck, MD, National Human Genome Research Institute, NIH, 49 Convent Drive, Building 49, Room 4A14, Bethesda, MD 20892.E-mail: JPuck@mail.nih.gov.

0091-6749/\$30.00

(C) 2005 American Academy of Allergy, Asthma and Immunology doi:10.1016/j.jaci.2004.10.012

\section{Abbreviations used}

BMT: Bone marrow transplant

DHMH: Department of Health and Mental Hygiene

NEMO: Nuclear factor kappa B essential modulator

PKU: Phenylketonuria

SCID: Severe combined immunodeficiency

TCR: T-cell receptor

TREC: T-cell receptor excision circle

defects in both cellular and humoral immunity. ${ }^{1-4}$ Infants with SCID die of infections in the first year of life unless immunity is reconstituted by bone marrow transplantation (BMT), ${ }^{5,6}$ enzyme replacement, ${ }^{7}$ or, in some recent cases, gene therapy. ${ }^{8-11}$ There is no current screening program for SCID, which is caused by diverse mutations in any of at least 11 known genes and others not presently known, as summarized in Table I. ${ }^{12-28}$

Screening newborns for treatable genetic disorders allows early intervention. ${ }^{29,30}$ After the introduction by Guthrie of filter paper spotted with heel-stick blood to screen for phenylketonuria (PKU), ${ }^{31}$ all states in the United States test newborns for PKU, hypothyroidism, and galactosemia. ${ }^{29,32}$ New tests use tandem mass spectrometry to detect many additional metabolic disorders $^{30,33}$ and DNA analysis to diagnose specific mutations causing cystic fibrosis, hemoglobinopathies, and biotinidase deficiency. ${ }^{34-37}$ Screening programs are evolving to meet the growing number of conditions that can be identified and treated. ${ }^{29,30,38}$

A recent report on primary immunodeficiencies from the Centers for Disease Control and Prevention noted that SCID meets many of the accepted criteria for newborn screening. ${ }^{39}$ SCID is asymptomatic at birth, but it becomes fatal without treatment; effective treatment is available; and early intervention improves outcome. Infants receiving BMT before developing devastating infections have better survival at lower cost than those whose treatment is delayed. ${ }^{5,6,40}$ Indeed, Myers et $\mathrm{al}^{40}$ reported $95 \%$ survival among infants undergoing transplantation in the first month of life compared with only $70 \%$ for those treated after 3 months.

Arguments against newborn screening for SCID include its low incidence and the lack of a practical test. The true incidence of SCID is unknown; estimates of 


\begin{tabular}{|c|c|c|c|c|c|}
\hline \multirow[b]{2}{*}{ Gene defect } & \multirow[b]{2}{*}{ Molecular pathogenesis } & \multirow[b]{2}{*}{$\%$ of SCID cases* } & \multicolumn{3}{|c|}{$\begin{array}{l}\text { Characteristic lymphoctye } \\
\text { subpopulations }\end{array}$} \\
\hline & & & $\mathbf{T}$ cells $\dagger$ & B cells & Natural killer cells \\
\hline$I L 2 R G(\mathrm{X}$-linked $)$ & $\begin{array}{l}\text { Failure of IL-2 receptor (common) } \gamma \text {-chain } \\
\quad \text { signaling by cytokines IL-2, }-4,-7,-9,-15,-21^{16}\end{array}$ & $45-50$ & Low/absent & Present & Absent \\
\hline$A D A$ & Adenosine deaminase deficiency ${ }^{7}$ & 16 & Low/absent & Absent & Absent \\
\hline$I L 7 R$ & Failure of signaling through IL-7 receptor ${ }^{18}$ & 9 & Low/absent & Present & Present \\
\hline$J A K 3$ & $\begin{array}{l}\text { Failure of Janus kinase } 3 \text { activation by common } \\
\gamma \text {-chain }{ }^{17}\end{array}$ & 6 & Low/absent & Present & Absent \\
\hline DCLREIC $\ddagger$ & Failure of antigen receptor rearrangement ${ }^{19}$ & $<5$ & Absent & Absent & Present \\
\hline$R A G 1 \ddagger$ & Failure of antigen receptor rearrangement ${ }^{19}$ & $<2$ & Absent & Absent & Present \\
\hline$R A G 2 \ddagger$ & Failure of antigen receptor rearrangement ${ }^{19}$ & $<2$ & Absent & Absent & Present \\
\hline$C D 45$ & $\begin{array}{l}\text { Lack of a cell surface protein tyrosine phosphatase } \\
\text { receptor (PTPRC), required for T- and B-cell } \\
\text { activation by antigen }\end{array}$ & Rare & Low/absent & Present & $\begin{array}{l}\text { Low, maybe } \\
\text { variable }\end{array}$ \\
\hline$T C R D$ & T-cell receptor $\delta$ chain deficiency ${ }^{22}$ & Very rare & Low/absent & Present & Present \\
\hline$L C K$ & $\begin{array}{l}\text { Lack of lymphocyte tyrosine kinase p56lck, required } \\
\text { for T-cell development and activation }\end{array}$ & Very rare & Low/absent & Present & Present \\
\hline FOXN1 & $\begin{array}{l}\text { Lack of forkhead box N1transcription factor, } \\
\text { required for thymus and hair follicle development } \\
\text { (ortholog of nude mouse) })^{24}\end{array}$ & Very rare & Low/absent & Present & Present \\
\hline Deletion of Chr 22q11 & $\begin{array}{l}\text { Complete DiGeorge syndrome with thymus aplasia; } \\
\text { part of DiGeorge-Velocardiofacial syndrome }\end{array}$ & Rare & Absent & Variable & Present \\
\hline Currently unknown & $\begin{array}{l}\text { Unknown, including reticular dysgenesis }{ }^{26} \text { and } \\
\text { congenital anomaly syndromes with } \text { SCID }^{27,28}\end{array}$ & Each one rare & Low/absent & Variable & Variable \\
\hline
\end{tabular}

*Based on Buckley, ${ }^{15}$ Antoine et al, ${ }^{6}$ and unpublished estimates (J Puck).

$\uparrow$ Some patients have substantial numbers of maternally derived T cells at time of diagnosis.

$\ddagger \mathrm{T}$ - and B-cell antigen receptor genes include the DNA cross-link repair protein 1C (DCLRE1C, or ARTEMIS) and the recombinase activating genes (RAG).

1/100,000 births $^{39}$ exclude patients who die before their immunodeficiency is recognized. The incidences of galactosemia and biotinidase deficiency, included in many current screening programs, are comparable at 1/60,000 and $1 / 80,000$, respectively. ${ }^{29,32}$ An inexpensive, highthroughput screening method for SCID is needed. Such a test should identify SCID caused by defects in known disease genes as well as SCID with unknown genotype. Characteristic lymphocyte phenotypes are associated with the different genotypes of SCID (Table I). Patients with $I L 2 R G$ and $J A K 3$ defects, for example, can make B cells and are designated $\mathrm{T}^{-} \mathrm{B}^{+}$SCID, whereas those with $R A G 1$ defects are $\mathrm{T}^{-} \mathrm{B}^{-}$. Natural killer cells are typically absent in patients with $I L 2 R G$ SCID but present in IL7R SCID. In some patients, regardless of genotype, maternal $\mathrm{T}$ cells are present at diagnosis in numbers substantial enough to cause spontaneous graft-versus-host disease. However, a very low number of patient $\mathrm{T}$ cells is a feature common to all SCID genotypes. Thus, attributes of infant $\mathrm{T}$ cells could provide the basis for a universal SCID screening test.

Normal thymic maturation of $\mathrm{T}$ cells requires cutting and splicing of the DNA encoding the T-cell antigen receptor (TCR) genes to produce $\mathrm{T}$ cells with diverse antigen specificities. As a byproduct of this recombination, excised DNA forms episomal T-cell receptor excision circles (TRECs). One species, the $\delta$ Rec- $\varphi \mathrm{J} \alpha$ TREC, is produced late in maturation by $70 \%$ of developing human T cells that express $\alpha \beta$ TCRs. ${ }^{41-43}$ Quantitative PCR amplification across the joined ends of the $\delta \operatorname{Rec}-\varphi \mathrm{J} \alpha$
TREC reflects the number of recently formed $\mathrm{T}$ cells in peripheral blood. We have developed a newborn screening method for SCID based on measurement of TRECs from dried blood spots.

\section{METHODS}

\section{Samples}

Blood samples from healthy adults and from infants newly diagnosed with SCID were donated with consent under approved research protocols at the National Institutes of Health. SCID molecular diagnosis was performed by sequencing $I L 2 R G$ in male subjects as described ${ }^{16}$ and obtaining $J A K 3$ sequence (GeneDx, Rockville, Md) where indicated. Umbilical cord blood was obtained from routine deliveries via the National Disease Research Interchange (Philadelphia, Pa). Simulated blood spots were made by applying $50 \mu \mathrm{L}$ of blood to the $1.3-\mathrm{cm}$ circles on standard filter paper cards provided by the Maryland State Department of Health and Mental Hygiene (DHMH) (Baltimore, Md). The cards were air-dried and stored desiccated away from light. Actual, outdated newborn blood spots (stored $>6$ months desiccated at $-20^{\circ} \mathrm{C}$ ), for which screening had been completed, were provided by Dr Susan Panny and colleagues at the Maryland State DHMH after approval by the DHMH Institutional Review Board. Samples had been obtained in routine care nurseries from babies at 1 to 2 days of age or in premature and special care nurseries at 2 to 3 days of age. ${ }^{44}$ Identifying numbers were removed from the filters.

\section{T-Cell depleted simulated Guthrie cards}

To model blood from SCID patients, adult blood was separated, depleted of $\mathrm{T}$ cells, and reconstituted as follows: after centrifugation, 
the buffy coat was aspirated and spun over Ficoll (MP Biomedicals, Irvine, Calif). The granulocyte/erythrocyte pellet was retained. Mononuclear cells were treated with anti-CD3 coated microbeads and passed through a magnetic separation system (MACS; Miltenyi Biotech, Auburn, Calif). T-cell depleted mononuclear and granulocyte fractions were added back to the platelet-rich plasma and erythrocytes from the original centrifugation. Immunophenotyping showed $1 \%$ of the lymphocytes of this mixture were T cells. Aliquots were spotted onto filter circles as above.

\section{DNA extraction}

Disks $3 \mathrm{~mm}$ in diameter were punched out of the dried spots. DNA was extracted by using a Gentra Systems kit (Minneapolis, Minn). Glycogen $1 \mu \mathrm{L}, 20 \mathrm{mg} / \mathrm{mL}$ (Invitrogen, Carlsbad, Calif), was added before precipitation. DNA was resuspended in $40 \mu \mathrm{L} \mathrm{H}_{2} \mathrm{O}$ and heated at $65^{\circ} \mathrm{C}$ for 1 hour. Quality and yield were assessed by spectrophotometry and visualization in agarose gels. Preliminary DNA isolations showed optimal yields from 2 punches, corresponding to about $6 \mu \mathrm{L}$ of blood.

\section{Quantitative real-time PCR}

Real-time PCR for $\delta$ Rec- $\varphi J \alpha$ TRECs used primer, probe, and control plasmid sequences of Douek et al. ${ }^{45}$ Each triplicate reaction of $20 \mu \mathrm{L}$ contained $4 \mu \mathrm{L}$ DNA, TaqMan $2 \times$ PCR Master Mix (Applied Biosystems, Foster City, Calif), $500 \mathrm{nmol} / \mathrm{L}$ forward and reverse primers (F, 5'-cacatccctttcaaccatgct; R, 5' -gccagctgcagggtttagg), and $150 \mathrm{nmol} / \mathrm{L}$ probe (FAM-5' -acacctctggttttgtaaaggtgcccactTAMRA). Samples were heated at $95^{\circ} \mathrm{C}$ for 5 minutes and then given 40 cycles of $95^{\circ} \mathrm{C}$ for 30 seconds, $60^{\circ} \mathrm{C}$ for 1 minute (7900HT Prism Sequence Detection System; Applied Biosystems). PCR for $\beta$-actin used identical cycles with $1 \mu \mathrm{L}$ of DNA, $375 \mathrm{nmol} / \mathrm{L}$ primers (F, 5' -tcacccacactgtgcccatctacgag; R, 5' -cagcgaaccgctcattgccatgg), and $250 \mathrm{nmol} / \mathrm{L}$ probe (FAM-5'-atgccetcccccatgccatcetgegtTAMRA). TREC and $\beta$-actin copy number were calculated relative to standard curves generated from serially diluted plasmids.

\section{Statistical analysis}

Relationships between DNA concentrations, TRECs, and $\beta$-actin copies were determined by linear regression. Analysis of the variance was used to compare samples from routine versus special care nurseries. A test based on simulating the Kolmogorov-Smirnov statistic, adjusting for having to fit mean and variance, was used to establish whether values were normally distributed.

\section{RESULTS}

Although simple to collect, dried blood spots vary widely in cellular content and extractable material, as illustrated by the 10-fold variation in DNA yields in our samples from 0.12 to $1.35 \mu \mathrm{g}$ (mean, $0.46 \mu \mathrm{g}$ ) per 2 punches. Nonetheless, preliminary experiments showed significant positive correlations between TRECs and DNA content; $\beta$-actin copies and DNA content; and TRECs and $\beta$-actin copies (not shown). Multiple independent DNA preparations and PCR reactions were performed on a series of spots made from cord and adult blood, demonstrating that TREC number was reproducible for a given individual's sample (Fig 1, A). Mean TREC values for cord and adult blood were 740 and 164 , respectively, consistent with published observations that cord blood has more newly formed $\mathrm{T}$ cells and TRECs. ${ }^{41,46}$ To assure that adequate DNA for PCR had been extracted, TREC values
A

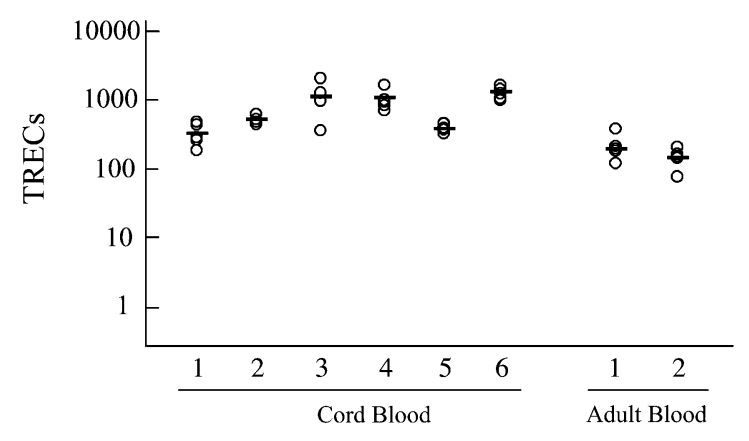

B

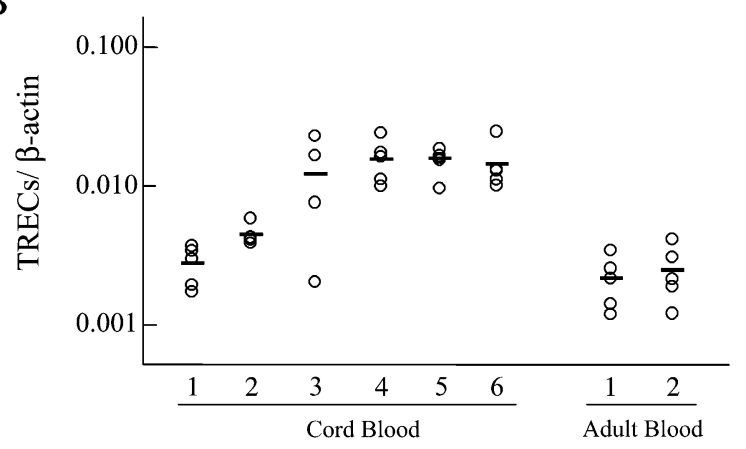

$\mathrm{C}$

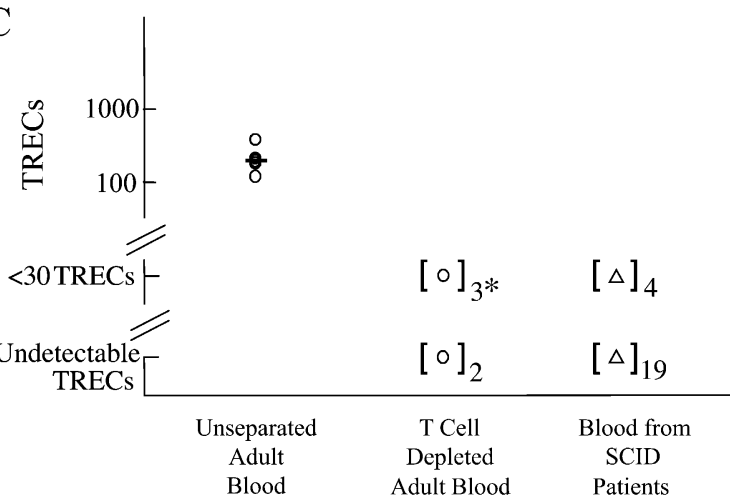

FIG 1. Cord blood and adult blood TRECs (A) and TREC/ $\beta$-actin (B) in replicate DNA isolations from 2 punches representing $6 \mu \mathrm{L}$ of blood dried on filters. C, TRECs from filters with unseparated vs T-celldepleted adult blood (circles) and from SCID infant blood (triangles). Bars represent mean of replicate samples from the same subject; *numbers of samples with the same value are in brackets.

were normalized to copies of $\beta$-actin genomic DNA (Fig 1, $B)$. The mean cord blood TREC/ $\beta$-actin was 0.0109 (median, 0.0125; range, 0.0028-0.0158; SEM, 0.0014), 4-fold higher than the adult mean of 0.0024 (median, 0.0022; range, 0.0013-0.0042; SEM, 0.0003).

To model SCID blood, an aliquot of adult blood was depleted of $\mathrm{T}$ cells, spotted onto filters, and used for 5 DNA extractions and PCR quantitations of TREC and $\beta$-actin (Fig 1, $C$, circles). Two of the T-cell-depleted DNA preparations had no amplification, whereas 3 had minimal amplification, corresponding to $<30$ copies, the lower limit of detection in standard serial dilutions. 
TABLE II. Clinical and molecular data and TREC analysis at time of diagnosis in 23 patients

\begin{tabular}{|c|c|c|c|c|c|c|c|c|c|c|c|}
\hline \multirow{2}{*}{$\begin{array}{l}\text { Case } \\
\text { code }\end{array}$} & \multirow{2}{*}{$\begin{array}{c}\text { Age } \\
\text { diagnosed }\end{array}$} & \multirow{2}{*}{\multicolumn{2}{|c|}{$\begin{array}{r}\text { Family } \\
\text { Sex history* }\end{array}$}} & \multirow[b]{2}{*}{ Clinical history } & \multirow{2}{*}{$\begin{array}{c}\text { Total } \\
\text { lymphocytes } \dagger\end{array}$} & \multirow[b]{2}{*}{ T cells $\ddagger$} & \multirow[b]{2}{*}{ B cells§ } & \multirow[b]{2}{*}{ NK cells $\|$} & \multirow[b]{2}{*}{ SCID genotype } & \multicolumn{2}{|c|}{$\begin{array}{l}\text { PCR from } \\
\text { blood spot }\end{array}$} \\
\hline & & & & & & & & & & TRECs & $\beta$-actin \\
\hline 340 & $2 \mathrm{~d}$ & M & + & Healthy & 801 & 15 & 136 & 68 & $I L 2 R G$ & $-* *$ & + \\
\hline 126 & $1 \mathrm{wk}$ & $\mathrm{M}$ & + & Healthy & Not available & $\mathbf{0}$ & 444 & 3 & $J A K 3$ & - & + \\
\hline 220 & $2 \mathrm{wk}$ & M & + & $\begin{array}{l}\text { 27-wk gestation, } \\
\text { respiratory distress }\end{array}$ & $\underline{2820}$ & 24 & 448 & NA & $I L 2 R G$ & - & + \\
\hline 140 & $1 \mathrm{mo}$ & M & + & Healthy & 441 & 9 & 361 & 13 & $I L 2 R G$ & - & + \\
\hline 339 & $3 \mathrm{mo}$ & $\mathrm{F}$ & + & $\begin{array}{l}\text { Thrush, pneumonia, } \\
\text { adenovirus, FTT } \dagger+ \\
\text { (died in post-BMT } \\
\text { period) }\end{array}$ & 1740 & $\mathbf{0}$ & 1672 & $\mathbf{0}$ & $I l 2 R G$ & - & + \\
\hline 344 & $3 \mathrm{mo}$ & M & & $\begin{array}{l}\text { Diarrhea, thrush, } \\
\text { Parainfluenza } 3 \text {, sepsis }\end{array}$ & $\underline{2780}$ & $\mathbf{0}$ & 2724 & $\mathbf{0}$ & $I L 2 R G$ & - & + \\
\hline $345 \mathrm{~A}$ & $4 \mathrm{mo}$ & M & & $\begin{array}{l}\text { FTT, chronic } \\
\text { upper respiratory } \\
\text { infections, rash }\end{array}$ & 446 & 101 & 96 & 167 & $\begin{array}{l}\text { Not } I L 2 R G \\
\quad \text { or } J A K 3\end{array}$ & - & + \\
\hline $345 B$ & $4 \mathrm{mo}$ & M & & $\begin{array}{l}\text { FTT, chronic } \\
\text { upper respiratory } \\
\text { infections, rash }\end{array}$ & 623 & 204 & 146 & 158 & $\begin{array}{l}\text { Not } I L 2 R G \\
\quad \text { or } J A K 3\end{array}$ & - & + \\
\hline 346 & $4 \mathrm{mo}$ & M & & Diarrhea, PJP $+\neq$ & 987 & $\mathbf{0}$ & 809 & 138 & Not $I L 2 R G$ & - & + \\
\hline $318-2$ & 4 mo & M & + & Thrush (brother of 318-1) & 2160 & 22 & 1805 & NA & $I L 2 R G$ & - & + \\
\hline 336 & 4 mo & M & + & $\begin{array}{l}\text { Cyanosis, pneumonia } \\
\text { (maternal uncles died } \\
\text { of infections and } \\
\text { immune insufficiency) }\end{array}$ & $\overline{395}$ & 16 & 371 & $\mathbf{0}$ & $I L 2 R G$ & - & + \\
\hline 349 & $4 \mathrm{mo}$ & M & & PJP, rash eczema & 1210 & 35 & 236 & $\mathbf{0}$ & $I L 2 R G$ & - & + \\
\hline 317 & $6 \mathrm{mo}$ & M & & FTT, Rotavirus, PJP & 1000 & 160 & 800 & $\mathbf{0}$ & $I L 2 R G$ & - & + \\
\hline 348 & $6 \mathrm{mo}$ & $\mathrm{F}$ & & FTT, Rotavirus, PJP & 1020 & 10 & 950 & $\mathbf{7 0}$ & AR, not $J A K 3$ & Trace $\S \S$ & + \\
\hline 352 & $6 \mathrm{mo}$ & $\mathrm{F}$ & & FTT, PJP & 2390 & 93 & 2008 & NA & $\mathrm{AR}$ & - & + \\
\hline 320 & $7 \mathrm{mo}$ & M & & PJP & $\overline{3348}$ & 10 & 3367 & 34 & $I L 2 R G$ & Trace & + \\
\hline 321 & $7 \mathrm{mo}$ & M & & $\begin{array}{l}\text { PJP, absent } \\
\quad \text { radii and thumbs }\end{array}$ & $\overline{396}$ & 40 & 350 & 0 & $\begin{array}{l}\text { SCID with } \\
\text { anomalies }\end{array}$ & Trace & + \\
\hline 353 & $7 \mathrm{mo}$ & $\mathrm{F}$ & & PJP (died before BMT) & 1300 & 28 & 1057 & 285 & $\mathrm{AR}$ & - & + \\
\hline 354 & $7 \mathrm{mo}$ & $\mathrm{M}$ & & FTT, diarrhea, PJP & 1080 & $\mathbf{0}$ & 921 & 38 & Not $I L 2 R G$ & - & + \\
\hline 326 & $8 \mathrm{mo}$ & $\mathrm{M}$ & & FTT, diarrhea, PJP & 710 & 24 & 670 & 14 & $J A K 3$ & - & + \\
\hline 342 & $9 \mathrm{mo}$ & M & & $\begin{array}{r}\text { FTT, diarrhea, } \\
\text { dehydration }\end{array}$ & 2750 & 82 & 2336 & 385 & $I L 2 R G$ & - & + \\
\hline $318-1$ & $12 \mathrm{mo}$ & M & & $\begin{array}{l}\text { FTT, diarrhea, CMV, } \\
\text { bronchitis }\end{array}$ & 800 & 260 & 420 & 80 & $I L 2 R G$ & Trace & + \\
\hline 335 & $13 \mathrm{mo}$ & M & & $\begin{array}{l}\text { Eczema, elevated IgE, } \\
\text { HSV, Rotavirus, } \\
\text { Adenovirus, } \\
\text { pneumonia, sepsis }\end{array}$ & $1000-\underline{2448}$ & $268(\mathrm{DR}+, \mathrm{RO}+)$ & 558 & 285 & $\begin{array}{l}\text { Not } I L 2 R G \\
\text { or } J A K 3\end{array}$ & - & + \\
\hline 350 & $3 \mathrm{mo}$ & $\mathrm{F}$ & & $\begin{array}{l}\text { Rash, PJP, mother } \\
\text { with incontinentia } \\
\text { pigmenti }\end{array}$ & 4550 & 4573 & 939 & NA & $\begin{array}{l}\text { Not SCID; } \\
\text { NEMO mutation }\end{array}$ & 596 & + \\
\hline 329 & $5 \mathrm{mo}$ & M & & PJP & 1400 & 506 & 458 & 60 & $\begin{array}{c}\text { Not SCID; T cells } \\
\text { normal at } 1 \mathrm{y}\end{array}$ & 624 & + \\
\hline 343 & $7 \mathrm{mo}$ & M & & $\begin{array}{l}\text { FTT, } 3 \text { episodes } \\
\text { of pneumonia, died } \\
\text { after } 2 \text { BMT attempts }\end{array}$ & 2226 & 140 & 4 & 171 & Not $I L 2 R G$ & -\|\| & +\|\| \\
\hline
\end{tabular}

Abnormal values are in bold type. Values approaching normal range are underlined.

$N K$, Natural killer; $A R$, autosomal recessive; $C M V$, cytomegalovirus; $H S V$, herpes simplex virus.

*Known sibling(s) and/or maternal male uncle(s) with SCID or severe immune compromise in infancy.

$\dagger$ Total white blood counts for the patients ranged from 5,110 to $15,300 / \mu \mathrm{L}$; total lymphocytes/ $\mu \mathrm{L}, 10$ th to 90 th percentiles ${ }^{47}$ : 0-3 mo, $3400-7600 / \mu \mathrm{L} ; 3-6 \mathrm{mo}$,

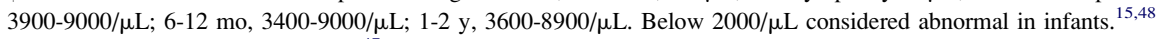

$\$ 10$ th to 90th percentiles for T cells ${ }^{47}: 0-3 \mathrm{mo}, 2500-5500 / \mu \mathrm{L}, 3-6 \mathrm{mo}, 2500-5600 / \mu \mathrm{L} ; 6-12 \mathrm{mo}, 1900-5900 / \mu \mathrm{L} ; 1-2 \mathrm{y}, 2100-6200 / \mu \mathrm{L}$.

$\S 10$ th to 90 th percentiles for B cells ${ }^{47}$ : 0-3 mo, 300-2000/ $\mu \mathrm{L} ; 3-6 \mathrm{mo}, 430-3000 / \mu \mathrm{L} ; 6-12 \mathrm{mo}, 610-2600 / \mu \mathrm{L} ; 1-2 \mathrm{y}, 720-2600 / \mu \mathrm{L}$.

$\| 10$ th to 90 th percentiles for NK cells ${ }^{47}$ : 0-3 mo, $170-1100 / \mu \mathrm{L} ; 3-6 \mathrm{mo}, 170-830 / \mu \mathrm{L} ; 6-12 \mathrm{mo}, 160-950 / \mu \mathrm{L} ; 1-2 \mathrm{y}, 180-920 / \mu \mathrm{L}$.

I2 determinations performed for each sample.

**No PCR product detectable.

$\dagger \dagger$ Failure to thrive (weight $<5 \%$ and falling behind on growth curve).

†Pnemonia due to Pneumocystis jiroveci (formerly $P$ carinii).

$\S \S$ Trace PCR detected below threshold level of $30 \mathrm{TRECs} / 2$ punches.

||||DNA from newborn screening filter spot; no other sample available. 
Our laboratory receives samples for mutation testing for SCID. In 2002, 34 newly diagnosed infants with confirmed SCID who were born in the US had blood, cell lines, or DNA submitted for mutation diagnosis; 19 (56\%), had disease-causing mutations in IL2RG. Beginning in 2003, blood submitted in excess of the amount needed for diagnostic studies was spotted onto a filter and dried for TREC analysis. Twenty-three spots were analyzed from newly diagnosed SCID patients, whose characteristics are summarized in Table II. The 3 female and 20 male patients included 2 affected brothers in family 318 and twins in family 345 . Four patients were diagnosed in the first month of life, all recognized to be at risk for SCID because of a positive family history. Although one of these infants had respiratory difficulties associated with prematurity, none had infections or failure to thrive as a result of SCID. Three other infants, 339, 318-2, and 336, had known immunodeficiency in siblings or maternal uncles, but they were not investigated by medical providers before onset of infectious complications of SCID. All patients were referred to BMT centers for treatment. Clinical features (including 2 deaths caused by infections with onset before BMT) and lymphocyte phenotypes are indicated. Twelve of the 23 cases $(52 \%)$ had defects in $I L 2 R G$.

Duplicate DNA isolations from blood spots of all 23 infants had detectable $\beta$-actin. In contrast, 19 had no detectable TRECs, and 4 had $<30$ TRECs (Table II and Fig $1, C$, triangles). The patients with trace amounts of TREC amplification were 6 months of age or older at diagnosis. Of the latter, patient 348, diagnosed at 6 months, had autosomal recessive $\mathrm{T}^{-} \mathrm{B}^{+}$SCID with some natural killer cells; patients 320 and 321, diagnosed at 7 months, had Xlinked SCID and SCID with congenital anomalies, respectively; and patient 318-1, diagnosed at 12 months with X-linked SCID, had a younger affected brother with no detectable TRECs when diagnosed at 4 months of age.

Blood spots were also made from 2 additional immunodeficient patients (Table II, 329 and 350) for whom SCID was considered but later ruled out. TRECs were positive in samples from both patients. Patient 329 had intermittent lymphocytopenia and pneumocystis pneumonia at 5 months, but by 1 year his lymphocytopenia had resolved without a definite diagnosis. Patient 350 and her mother, who had incontinentia pigmenti, were found to have a previously reported, disease-associated missense mutation of the nuclear factor kappa B essential modulator (NEMO), a condition in which naïve T cells are produced normally, but memory $\mathrm{T}$ cells are not. ${ }^{49,50}$

To measure performance of the TREC assay on actual newborn screening spots, we collected an arbitrary number of sequential, outdated, anonymous Guthrie filters being discarded after testing. Enough saturated blood area for our assay was present on 242 filters. Repeated DNA isolation and PCR were done on samples that had either $<1000$ $\beta$-actin copies or $<30$ TRECs. Three were rejected for failure to yield DNA that could be amplified for $\beta$-actin, leaving 140 cards from routine and 99 from special care nurseries. Mean TREC number for all 239 samples was 1020; the mean (median) ratio of TRECs to $\beta$-actin copies
A

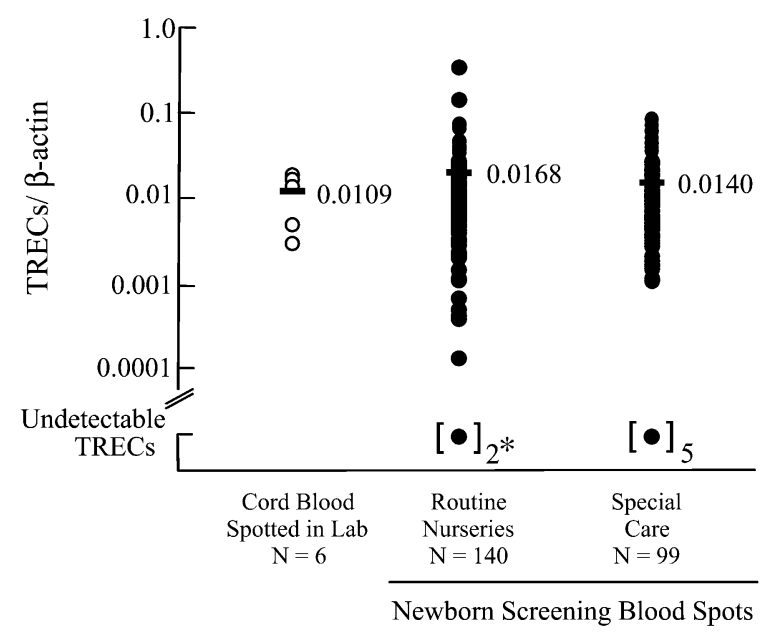

B

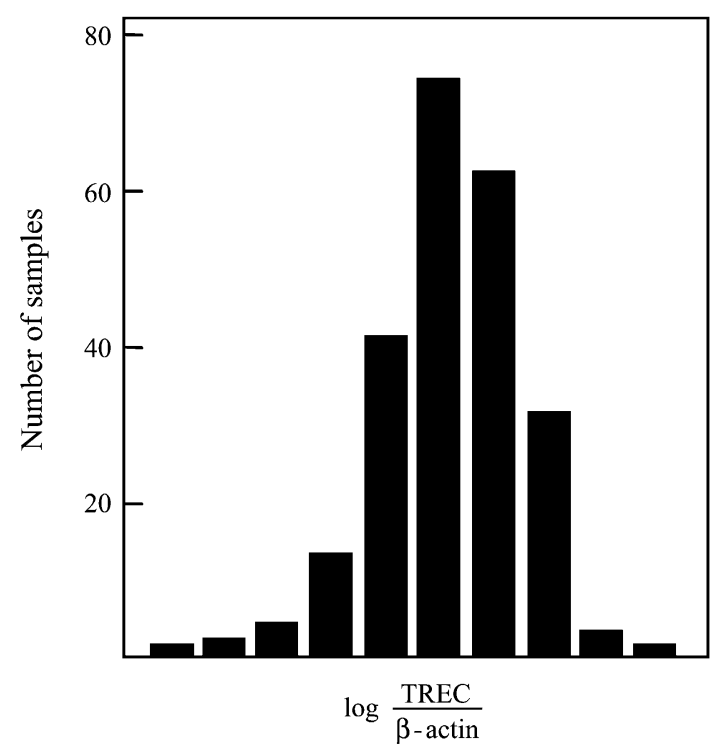

FIG 2. A, TREC/ $\beta$-actin from filters made in lab (open circles) and actual Guthrie cards (filled circles) from newborns in routine (center) and special care nurseries (right). N, Total samples/group; bar, mean; *numbers of samples with undetectable TRECs. B, Distribution of $\log [$ TREC/( $\beta$-actin $)]$ values in 232 Guthrie cards from all nurseries.

was $0.0168(0.0120)$ for samples from routine nurseries and $0.0140(0.0086)$ from special care nurseries, comparable to filters spotted in the laboratory from cord blood (Fig 2, A). Two spots from routine and 5 from special care nurseries had no detectable TRECs, but they had $\beta$-actin amplification. Although blood from a SCID patient would have this profile, these results were almost certainly false positives, given our small sample size. The function $\log [$ TRECs/( $\beta$-actin) $]$ evaluated for all samples with nonzero values of TREC and $\beta$-actin was normally distributed (Fig 2,B). Means and ranges for this function did not differ between routine versus special care nurseries, and a 1-way 
analysis of variance showed no difference for $\log [\mathrm{TREC} /$ ( $\beta$-actin)] between the nursery types $(P=.73)$.

We were able to retrieve the actual newborn screening cards from 2 patients subsequently diagnosed with SCID, patients 126 and 343 (Table II). Copy numbers of $\beta$-actin, 17,173 and 38,026 , respectively, confirmed that sufficiently pure DNA had been obtained for PCR, but TRECs were undetectable for both patients. Patient $343 \mathrm{had} \mathrm{T}^{-} \mathrm{B}^{-}$ SCID diagnosed with failure to thrive at 7 months; despite 2 BMTs, his immune function was not restored, and he died at the age of 2 years.

\section{DISCUSSION}

This study addresses previously unsatisfied criteria for newborn population screening for SCID: unavailability of incidence data and absence of an appropriate screening test. Paradoxically, the true incidence of SCID will be learned only through population screening. However, a minimum incidence can be estimated from our identification of 19 infants with XSCID mutations in a year and the annual US birthrate of $4,000,000 .{ }^{32}$ If blood from every XSCID infant born in the US were submitted to our laboratory for $I L 2 R G$ mutation detection, the incidence of XSCID would be $1 / 210,000$. Given that X-linked IL2RG defects account for about half of all SCID, there must be at least 38 SCID cases annually or at least 1/105,000 births. Other laboratories performing molecular diagnosis for XSCID make this an underestimate, and at least 2 additional lines of evidence indicate that SCID is actually more frequent. First, cases are recognized only in retrospect on diagnosis of a subsequent affected child in a family (Table II, patient 336). Furthermore, in a 1997 survey, parents ascertained through a subsidized SCID family conference were highly educated and had a median income nearly double the national average, suggesting that recognition of SCID is related to family resources. ${ }^{51}$ Although heritable, SCID is most often sporadic. ${ }^{16}$ Moreover, positive family history does not guarantee early diagnosis, as illustrated by 3 of 7 patients with positive family history in Table II not diagnosed before onset of infections. Immune evaluation is often omitted in newborns with congenital anomalies or incomplete manifestations of chromosome 22q11 deletion.

A total lymphocyte count has been suggested as a screen for SCID that could be performed on cord blood locally in nurseries. Although a pilot series identified most newborns with SCID, around 10\% of SCID samples had lymphocyte counts approaching normal values as a result of the presence of high numbers of $\mathrm{B}$ cells or maternal lymphocytes. ${ }^{14,39}$ Similarly, of our 23 newly diagnosed SCID patients, $7 \mathrm{had}>2000$ lymphocytes $/ \mu \mathrm{L}$ at the time of diagnosis (Table II), although no information is available for them as newborns. Universal screening by lymphocyte counts would also require costly liquid blood collection.

Mutation screening is possible with DNA extracted from dried blood spots, but for all SCID genes a wide variety of mutations occur. For example, hundreds of mutations in the cytokine receptor gene $I L 2 R G$ have been found to cause X-linked SCID. ${ }^{16}$ Mutation screening presents difficulties in interpretation of missense changes that have not previously been proven pathogenic, and only known SCID genes can be screened for mutations.

Screening dried blood spots for specific T-cell surface proteins has been suggested. An immunoassay for CD4 eluted from dried blood spots was claimed to be useful for monitoring patients with HIV infection. ${ }^{52}$ However, such assays have not been adapted for newborn screening, and both CD4 on monocytes and admixture of maternal T cells in circulating blood of newborns with SCID are potential sources of false normal results.

TRECs are a promising analyte for newborn screening because they represent newly formed $\mathrm{T}$ cells, they are stable in dried blood spots, and high-throughput screening can be implemented with low cost per test. Circulating Tcell numbers reflect thymic production of naïve cells and antigen-driven, peripheral expansion of cells in which TRECs become diluted. Healthy newborns have TREC numbers equal to $10 \%$ of T cells. ${ }^{46}$ In contrast, adult T cells expand predominantly by proliferation and have around 5 -fold fewer TRECs (Fig 1, $A$ and $B$ ). ${ }^{46}$ Thus, unlike T-cell surface proteins, TRECs in SCID newborn blood spots are unlikely to be derived from maternally transferred lymphocytes. Indeed, maternal T cells found in SCID patients have been reported to have a memory phenotype and to lack TRECs. ${ }^{15,53}$

Analysis of blood spotted onto filters confirmed that at the time of diagnosis SCID patients lack TRECs. Samples from all of 23 patients with various forms of SCID had $<30$ TRECs in two 3 -mm punches (equivalent to $<5$ TRECs per $\mu \mathrm{L}$ of circulating blood). One patient with NEMO deficiency and one with an undefined, transient T-cell lymphopenia had normal TRECs. Further testing will establish the range of cellular immunodeficiency phenotypes that can be found on the basis of low numbers of TRECs.

Importantly, the TREC test was abnormal in 2 actual Guthrie cards obtained from newborns with SCID. The clinical course of these affected infants illustrates the benefit of early diagnosis. Patient 126 has never been ill; a previously diagnosed affected older brother triggered presymptomatic diagnosis and led to his successful treatment by early haploidentical T-cell-depleted BMT. However, patient 343 was not diagnosed for 7 months, during which he experienced chronic diarrhea, failure to thrive, and 3 episodes of pneumonia. Despite 2 attempted haploidentical BMTs during long hospitalizations his immune function remained poor, and he died at 2 years of a sudden, overwhelming infection.

As with other screening tests, failure to amplify TRECs would trigger further screening and/or follow-up for definitive diagnostic tests. Our rates of failure to amplify TRECs were $1.5 \%$ in routine and $5 \%$ in special care nurseries. Failures in samples from infants in special care $\left(9 \%\right.$ of infants $\left.{ }^{54}\right)$ may reflect prematurity, stress, infection, or medications. Prospective screening with larger numbers of samples and follow-up of infants with low TRECs 
will reveal both clinical and technical factors that give false positive results as well as identify infants in need of treatment for immunodeficiency.

We thank Rebecca Buckley and Robert Vogt, Jr for helpful discussions; Susan Panny and staff at the Maryland DHMH for providing newborn screening cards; Stacie Anderson, Jolie Carter, Javier Chinen, Joie Davis, Dan Douek, Roxanne Fischer, Amy Hsu, and Martha Kirby for advice and assistance; Neal Oden of The EMMES Corporation for help with statistics; and the physicians and genetic counselors who referred patients to our study.

\section{REFERENCES}

1. Buckley RH, Schiff RI, Schiff SE, Markert ML, Williams LW, Harville TO, et al. Human severe combine immunodeficiency: genetic phenotypic, and functional diversity in one hundred eight infants. J Pediatr 1997; 130:378-87.

2. Conley ME, Notarangelo LD, Etzioni A. Diagnostic criteria for primary immunodeficiencies. J Clin Immunol 1999;93:190-7.

3. Belmont JW, Puck JM. T cell and combined immunodeficiency disorders. In: Schriver CR, Beaudet AL, Sly WS, Valle D, editors. The metabolic and molecular bases of inherited disease. New York: McGraw-Hill; 2003. p. 4751-83.

4. Buckley R. Primary immunodeficiency diseases due to defects in lymphocytes. Adv Immunol 2000;343:1313-24.

5. Buckley RH, Schiff SE, Schiff RI, Markert L, Williams LW, Roberts JL, et al. Hematopoietic stem-cell transplantation for the treatment of severe combined immunodeficiency. N Engl J Med 1999;340:508-16.

6. Antoine C, Muller S, Cant A, Cavazzana-Calvo M, Veys P, Vossen J, et al. Long-term survival and transplantation of haemopoiteic stem cells for immunodeficiencies: report of the European experience 1968-99. Lancet 2003;361:553-60.

7. Hershfield MS. PEG-ADA replacement therapy for adenosine deaminase deficiency: an update after 8.5 years. Clin Immunol Immunopathol 1995 76:S228-32.

8. Hacien-Bey-Abina S, Le Deist F, Carlier F, Bouneaud C, Hue C, De Villartay JP, et al. Sustained correction of X-linked severe combined immunodeficiency by ex vivo gene therapy. N Engl J Med 2002;288: 669-72.

9. Aiuti A, Slavin S, Aker M, Ficara F, Deola S, Mortellaro A, et al Correction of ADA-SCID by stem cell gene therapy combined with nonmyeloablative conditioning. Science 2002;296:2410-3.

10. Cavazzana-Calvo M, Thrasher A, Mavilio F. The future of gene therapy. Nature 2004:427:779-81.

11. Chinen J, Puck JM. Successes and risks of gene therapy in primary immunodeficiencies. J Allergy Clin Immunol 2004;113:595-603.

12. Ochs H, Smith CIE, Puck JM, editors. Primary immunodeficiency diseases: a molecular and genetic approach. New York: Oxford University Press; 1999.

13. Cooper MD, Lanier LL, Conley ME, Puck JM. Immunodeficiency disorders. In: Broudy VC, Prchal JT, Tricot GJ, editors. Hematology 2003, American Society of Hematology Education Program. Washington: Am Society of Hematology; 2003. p. 314-30.

14. Kalman L, Lindegren ML, Kobrynski L, Vogt R, Hannon H, Howard JT, et al. Mutations in genes required for T-cell development: IL7R, CD45, IL2RG, JAK3, RAG1, RAG2, ARTEMIS, and ADA and severe combined immunodeficiency: HuGE review. Genet Med 2004;6:16-26.

15. Buckley RH. Primary immunodeficiency diseases: dissectors of the immune system. Immunol Rev 2002;185:206-19.

16. Puck JM, Pepper AE, Henthorn PS, Candotti F, Isakov J, Whitwam T, et al. Mutation analysis of IL2RG in human X-linked severe combined immunodeficiency. Blood 1997;89:1968-77.

17. Roberts JL, Lengi A, Brown SM, Chen M, Zhou YJ, O'Shea JJ, et al. Janus kinase 3 (JAK3) deficiency: clinical, immunologic, and molecular analyses of 10 patients and outcomes of stem cell transplantation. Blood 2004;103:20009-18

18. Puel A, Ziegler SF, Buckley RH, Leonard WJ. Defective IL7R expression in $\mathrm{T}(-) \mathrm{B}(+) \mathrm{NK}(+)$ severe combined immunodeficiency. Nat Genet 1998;20:394-7.
19. de Villartay J-P, Poinsignon C, de Chasseval, Buck D, Le Guyader G, Villey I. Human and animal models of V(D)J recombination deficiency. Curr Opin Immunol 2003;15:592-8.

20. Kung C, Pingel JT, Heikinheimo M, Klemola T, Varkila K, Yoo LI, et al. Mutations in the tyrosine phosphastase CD45 gene in a child with severe combined immunodeficiency disease. Nat Med 2000;6: $343-5$

21. Tchilian EZ, Wallace DL, Wells RS, Flower DR, Morgan G, Beverley $\mathrm{PC}$, et al. A deletion in the gene encoding the CD45 antigen in a patient with SCID. J Immunol 2001;166:1308-13.

22. Dadi HK, Simon AJ, Roifman CM. Effect of CD3 $\delta$ deficiency on maturation of $\alpha / \beta$ and $\gamma / \delta$ T-cell lineages in severe combined immunodeficiency. N Engl J Med 2003;349:1821-8.

23. Goldman FD, Ballas ZK, Schutte BC, Kemp J, Hollenback C, Noraz N, et al. Defective expression of p56lck in an infant with severe combined immunodeficiency. J Clin Invest 1998;102:421-9.

24. Pignata C, Fiore M, Guzzetta V, Castaldo A, Sebastio G, Porta F, et al Congenital alopecia and nail dystrophy associated with severe functional T-cell immunodeficiency in two sibs. Am J Med Genet 1996;65: $167-70$

25. Markert ML, Sarzotti M, Ozaki DA, Sempowski GD, Rhein ME, Hale LP, et al. Thymus transplantation in complete DiGeorge syndrome: immunologic and safety evaluations in 12 patients. Blood 2003;102: 1121-30.

26. Bertrand Y, Muller SM, Casanova JL, Morgan G, Fischer A, Friedrich W, et al. Reticular dysgenesis: HLA non-identical bone marrow transplants in a series of 10 patients. Bone Marrow Transplant 2002;29: 759-62.

27. Tangsinmankong N, Day NK, Nelson RP Jr, Puck JM, Good RA. Severe combined immunodeficiency in an infant with multiple congenital abnormalities. J Allergy Clin Immunol 1999;103:1222-3

28. Gilroy RK, Coccia PF, Talmadge JE, Hatcher LI, Pirruccello SJ, Shaw BW Jr, et al. Donor immune reconstitution after liver-small bowel transplantation for multiple intestinal atresia with immunodeficiency. Blood 2004; 103:1171-4

29. Levy HL, Albers S. Genetic screening of newborns. Annu Rev Genomics Hum Genet 2000;1:139-77.

30. Khoury MJ, McCabe LL, McCabe ERB. Population screening in the age of genomic medicine. N Eng J Med 2003;348:50-8.

31. Meryash DL, Levy HL, Guthrie R, Warner R, Bloom S, Carr JR, et al Prospective study of early neonatal screening for phenylketonuria. N Engl J Med 1981;304:294-6.

32. U. S. National Screening Status Report. National Newborn Screening and Genetics Resource Center, updated 8/24/04. Available at: http: //www.genes-r-us.uthscsa.edu/. Accessed Aug. 28, 2004.

33. Carpenter KH, Wiley V. Application of tandem mass spectrometry to biochemical genetics and newborn screening. Clin Chim Acta 2002;322: $1-10$.

34. Zhang Y-H, McCabe LL, Wilborn M, Therrell BL, McCabe ERB. Application of molecular genetics in public health: improved follow-up in a neonatal hemoglobinopathy screening program. Biochem Med Metab Biol 1994;52:27-35.

35. Wilcken B, Wiley V. Newborn screening methods for cystic fibrosis. Paediatr Respir Rev 2003;4:272-7.

36. Wagener JS, Sontag MK, Accurso FJ. Newborn screening for cystic fibrosis. Curr Opin Pediatr 2003;15:309-15.

37. Dobrowolski SF, Angeletti J. Real time PCR assays to detect common mutations in the biotinidase gene and application of mutational analysis to newborn screening for biotinidase deficiency. Mol Genet Metab 2003; 78:100-7.

38. Wilson JMG, Jungner G. Principles and practice of screening for disease. Public Health Papers (Geneva: WHO) 1968;34:11-63.

39. Centers for Disease Control and Prevention. Applying public health strategies to primary immunodeficiency diseases: a potential approach to genetic disorders. MMWR 2004;52:1-29.

40. Myers LA, Patel DD, Puck JM, Buckley RH. Hematopoietic stem cell transplantation for severe combined immunodeficiency in the neonatal period leads to superior thymic output and improved survival. Blood 2002;99:872-8

41. Douek DC, McFarland RD, Keiser PH, Gage EA, Massey JM, Haynes $\mathrm{BF}$, et al. Changes in thymic function with age and during the treatment of HIV infection. Nature 1998;396:690-5. 
42. Verschuren MC, Wolvers-Tettero IL, Breit TM, Noordzij J, van Wering $\mathrm{ER}$, van Dongen JJ, et al. Preferential rearrangements of the $\mathrm{T}$ cell receptor-delta-deleting elements in human T cells. J Immunol 1997;158: 1208-16.

43. Hazenberg MD, Verschuren MC, Hamann D, Miedema F, van Dongen JJ. $\mathrm{T}$ cell receptor excision circles as markers for recent thymic emigrants: basic aspects, technical approach, and guidelines for interpretation. J Mol Med 2001;79:631-40.

44. Maryland Department of Health and Mental Hygiene Division for Newborn Screening and Follow-up. State of Maryland Family Health Administration. Available at: http://www.fha.state.md.us/genetics/html/ nbs_ndx.html. Accessed Aug. 28, 2004.

45. Douek DC, Vescio RA, Betts MR, Brenchley JM, Hill BJ, Zhang L, et al. Assessment of thymic output in adults after haematopoietic stem cell transplant and prediction of $\mathrm{T}$ cell reconstitution. Lancet 2000;355: 1875-81.

46. Schonland SO, Zimmer JK, Lopez-Benitez CM, Widmann T, Ramin KD, Goronzy JJ, et al. Homeostatic control of T-cell generation in neonates. Blood 2003;102:1428-34.

47. Shearer WT, Rosenblatt HM, Gelman RS, Oyomopito R, Plaeger S, Stiehm ER, et al. Lymphocyte subsets in healthy children from birth through 18 years of age: the Pediatric AIDS Clinical Trials Group P1009 Study. J Allergy Clin Immunol 2003;112:973-80.
48. Altman PL. Blood leukocyte values: man. In: Dittmer DS, editor. Blood and other body fluids. Washington: Federation of American Societies for Experimental Biology; 1961. p. 126-6.

49. Jain A, Ma CA, Liu S, Brown M, Cohen J, Strober W. Specific missense mutations in NEMO result in hyper-IgM syndrome with hypohydrotic ectodermal dysplasia. Nat Immunol 2001;2:223-8.

50. Orange JS, Jain A, Ballas ZK, Schneider LC, Geha RS, Bonilla FA. The presentation and natural history of immunodeficiency caused by nuclear factor kappaB essential modulator mutation. J Allergy Clin Immunol 2004;113:725-33.

51. Fanos JH, Davis J, Puck JM. Sib understanding of genetics and attitudes toward carrier testing for X-linked severe combined immunodeficiency. Am J Med Genet 2001;98:46-56.

52. Mwaba P, Cassol S, Pilon R, Chintu C, Janes M, Nunn A, et al. Use of dried whole blood spots to measure CD4+ lymphocyte counts in HIV-1-infected patients. Lancet 2003;362:1459-60.

53. Patel DD, Gooding ME, Parrott RE, Curtis KM, Haynes BF, Buckley RH. Thymic function after hematopoietic stem-cell transplantation for the treatment of severe combined immunodeficiency. N Engl J Med 2000;342:1325-32.

54. March of Dimes. Perinatal profiles: statistics for monitoring state maternal and infant health. 2003 edition. Available at: http://www. marchofdimes.com/peristats/. Accessed Aug. 28, 2004.

Don't miss a single issue of the journal! To ensure prompt service when you change your address, please photocopy and complete the form below.

Please send your change of address notification at least six weeks before your move to ensure continued service. We regret we cannot guarantee replacement of issues missed due to late notification.

\section{JOURNAL TITLE:}

Fill in the title of the journal here.

\section{OLD ADDRESS:}

Affix the address label from a recent issue of the journal here.

\section{NEW ADDRESS:}

Clearly print your new address here.

Name

Address

City/State/ZIP

COPY AND MAIL THIS FORM TO:

Elsevier Periodicals Customer Service

6277 Sea Harbor Dr

Orlando, FL 32887-4800
OR FAX TO:

800-225-6030

Outside the U.S.:

407-363-9661
OR PHONE:

800-654-2452

Outside the U.S.

407-345-4000
OR E-MAIL:

elspcs@elsevier.com 